\title{
Where Topsent went wrong: Aka infesta a.k.a. Aka labyrinthica (Demospongiae: Phloeodictyidae) and implications for other Aka spp.
}

\author{
Christine Hanna Lydia Schönberg*t and Lydia Beuck ${ }^{\dagger}$ \\ *Carl von Ossietzky University Oldenburg, Faculty V, Biology and Environmental Sciences, AG Animal Biodiversity and \\ Evolution, 26111 Oldenburg, Germany. Institut für Paläontologie, Friedrich-Alexander-Universität Erlangen-Nürnberg, \\ Loewenichstr. 28, 91054 Erlangen, Germany. *Corresponding author, e-mail: christine.schoenberg@uni-oldenburg.de
}

\begin{abstract}
Early descriptions for species of $A k a$ were poor in detail, and the only spicule type that occurs in this genus does not vary much between species, which led to taxonomic confusion. Moreover, the type specimens of five species of $A k a$ are lost, causing considerable problems. Mediterranean specimens of $A k a$ were identified as Aka labyrinthica (Hancock, 1849) by Topsent (1900), even though this species was originally described from the Indo-Pacific. All following publications on Mediterranean Aka accepted Topsent's decision. We assessed this problem with new samples from the Ionian Sea. Our material consisted of only one specimen of $A k a$, and we had to rely mainly on spicule characters for comparison with other species. We developed a system for species recognition solely based on spicular characters and biometry, involving a combination of the parameters oxea length, width, tip form and angle of curvature. This approach was surprisingly accurate. Forming ratios of the above parameters was less helpful, but can sometimes provide additional information. We identified our sample as Aka infesta (Johnson, 1899), and describe it as a minute-fistulate species with large, multicamerate erosion traces and stout, smooth oxeas. Our data further imply that A. labyrinthica sensu Hancock has not yet been found in the Mediterranean. Aka labyrinthica sensu Topsent is a collection of different species not including A. labyrinthica sensu Hancock.
\end{abstract}

\section{INTRODUGTION}

Taxonomy of the excavating genus $A k a$ (Demospongiae: Phloeodictyidae) is difficult. Skeletal characters alone have been regarded as of little assistance for species distinction of Aka spp., as the genus has only one spicule type, smooth oxeas. While they may be recognized as typical for $A k a$ (e.g. Rützler \& Stone, 1986), their form does not vary in an immediately obvious way between different species. Moreover, Aka oxeas have traditionally been considered to be very variable between sample locations (Topsent, 1900, 1904). Characters that may differ more clearly between species of $A k a-$ e.g. tissue layering, the amount of mucus exuded from fresh samples, unicamerate vs multicamerate erosion, papilla size and fistule length as in $<\mathrm{mm}$ vs $\mathrm{cm}$ scale-were rarely mentioned in previous descriptions and are only patchily available, making a comprehensive, morphology-based comparison impossible (e.g. Desqueyroux-Faúndez \& Valentine, 2002). General morphological characters have traditionally been poorly described (e.g. Johnson, 1899). In addition, early research provided spicule dimensions without giving information about the sample size, an error value or from which part of the body the spicules were taken (e.g. Hancock, 1849), which means that comparing 'mean' spicule dimensions and accepting them as similar may be a risky business. To make matters worse, the most important, historical type specimens have been lost and cannot be used to confirm earlier statements, or for redescriptions employing modern methods: A. labyrinthica and $A$. nodosa (Hancock, 1849; as Cliona) were destroyed during bombing of the Hancock Museum in the Second World War, and A. insidiosa, A. rodens and A. infesta (Johnson, 1899; as Acca) during a fire in 1980 in the Lisbon Museum.

While the Hancock specimens themselves are lost, we still have access to spicule slide preparations at the Hancock Museum in Newcastle upon Tyne, UK (see Rützler \& Stone, 1986). The slides are unavailable until early 2009, as the Hancock Museum is under reconstruction (D. Gordon, personal communication, curator of the collection). Also, the slides are preparations of acid-cleaned oxeas. Without developing a system purely based on characters of isolated spicules and providing additional criteria to the usual mean length and width measurements, the Hancock preparations may be assumed to be of little value.

As a consequence of the described difficulties, many of the existing identifications or reports of $A k a$ species will have to be regarded with great care. One particular case illustrates the predicaments we have to expect within this genus: ' $A$. labyrinthica' from the Mediterranean Sea and the Atlantic. Hancock (1849) described A. labyrinthica (as Cliona), but did not specify a type locality. However, he found this particular species in a giant clam (Tridacna gigas) that has a distribution 
1460 G.H.L. Schönberg and L. Beuck Aka infesta a.k.a. Aka labyrinthica

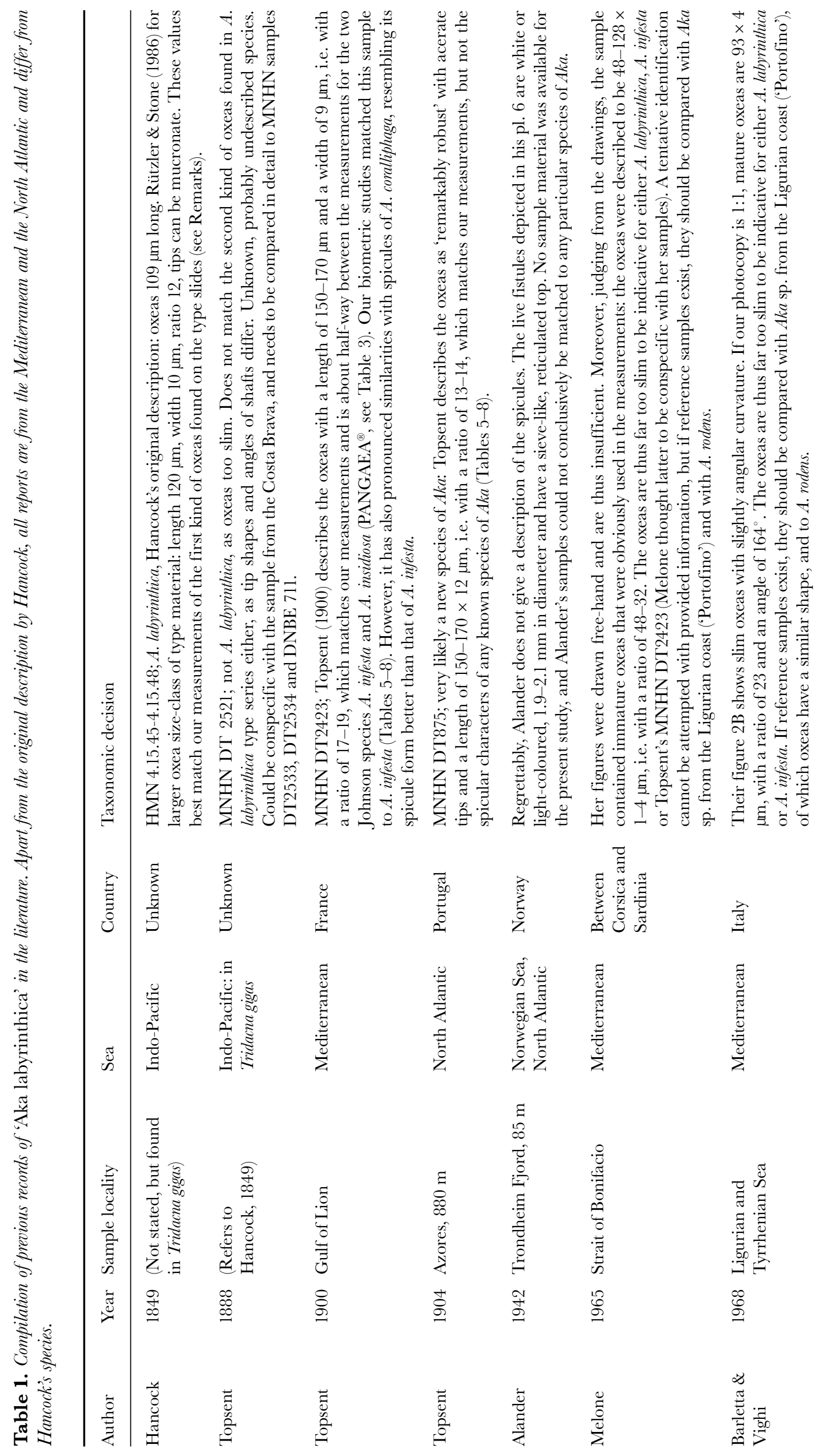


Aka infesta a.k.a. Aka labyrinthica

C.H.L. Schönberg and L. Beuck 1461

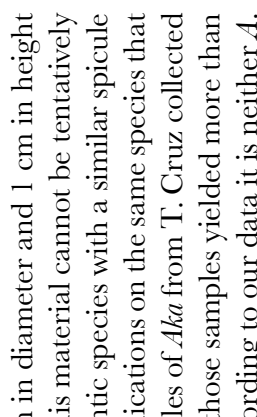

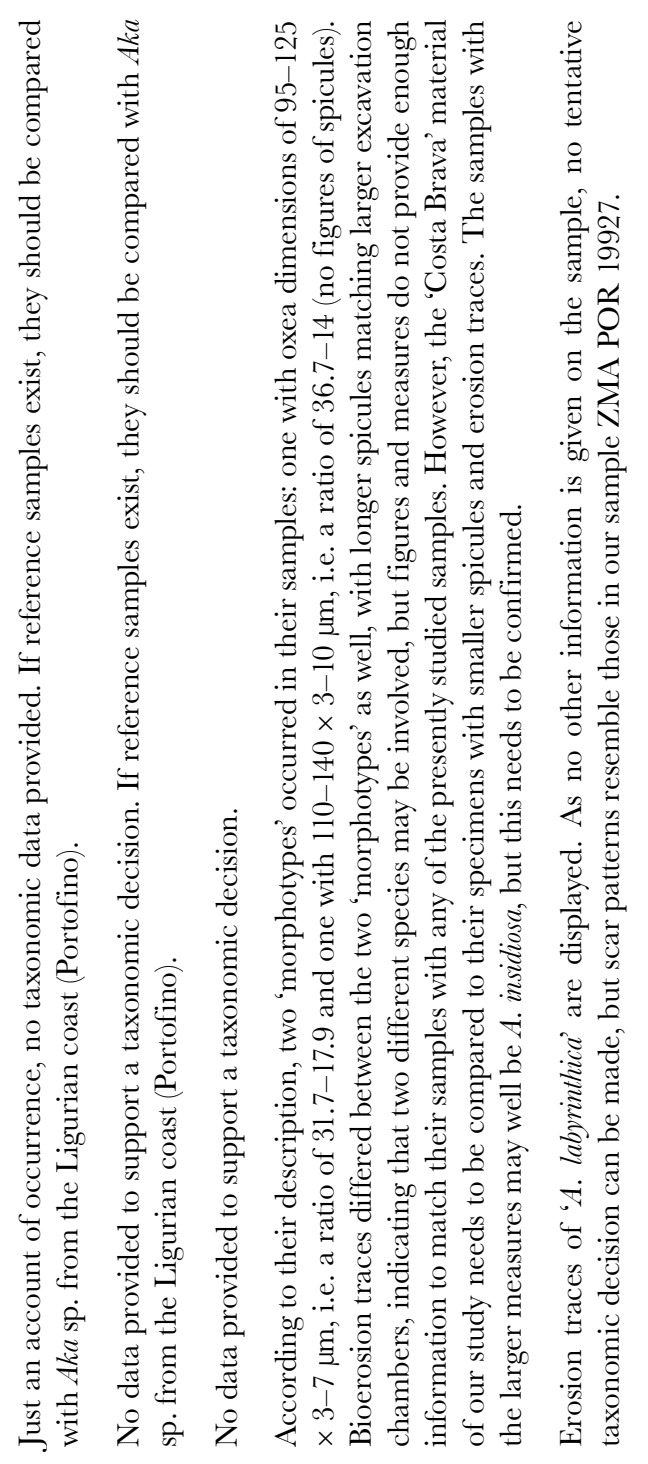

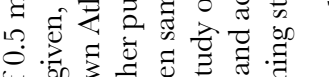

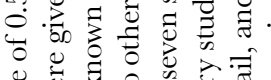

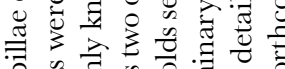

运甜

马

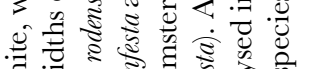

उत्य

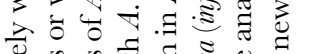

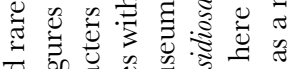

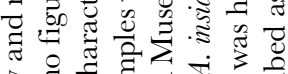

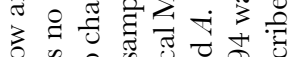

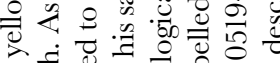

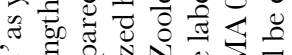

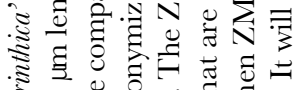

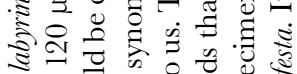

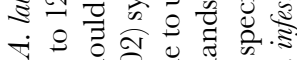

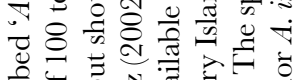

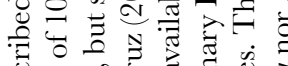

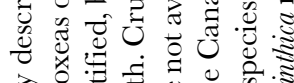

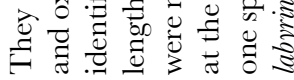

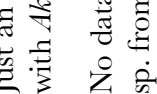

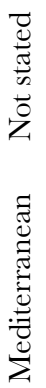
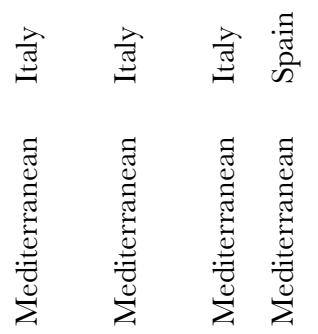

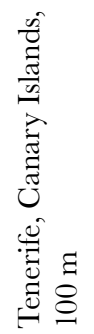

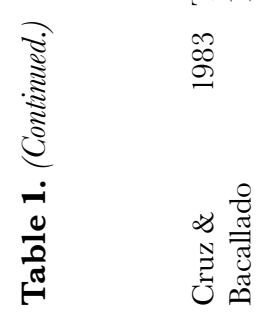

焉 

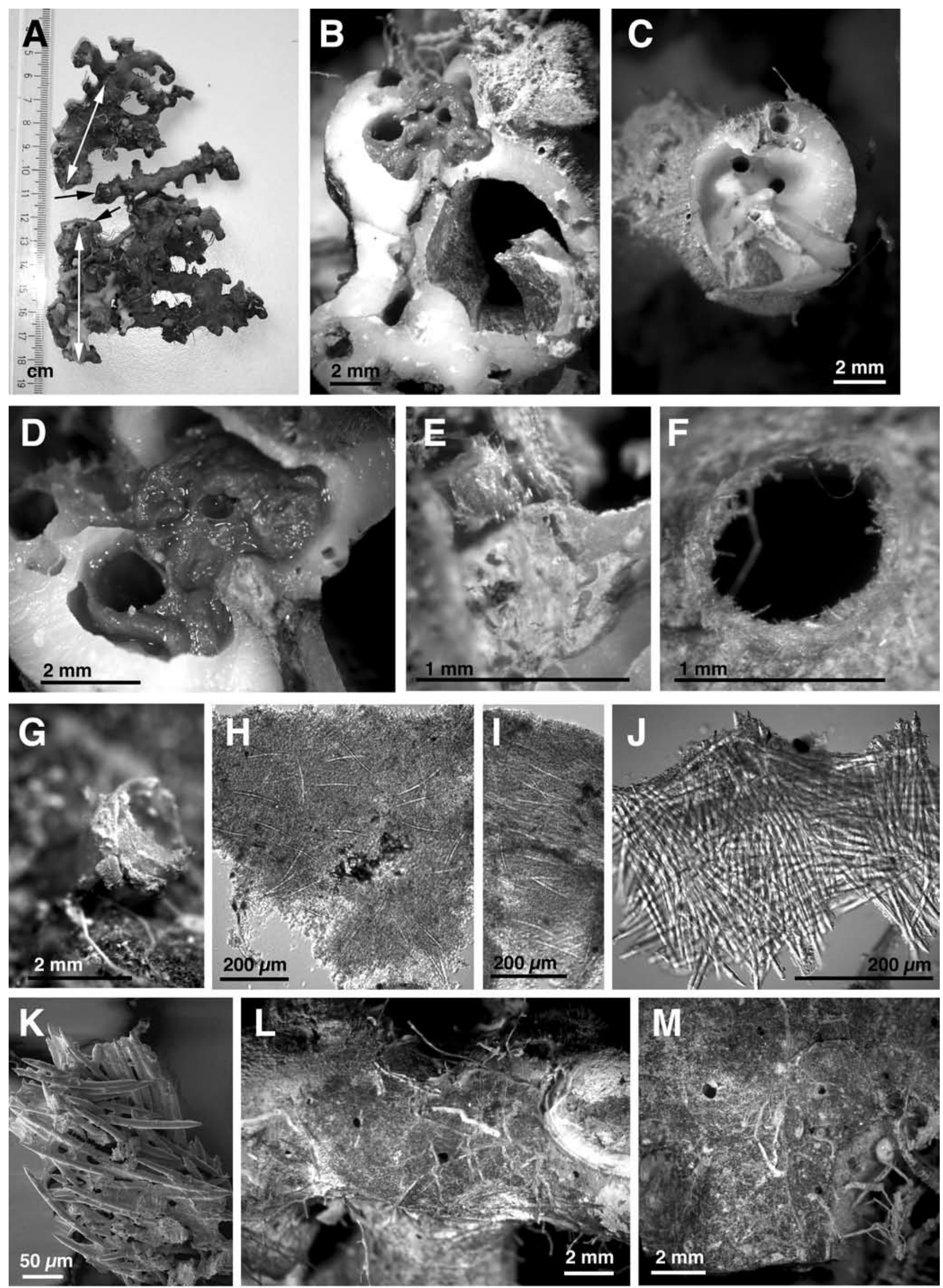

Figure 1. Morphological aspects of Aka infesta specimen ZMA POR 19927. (A) Overview of specimen of Madrepora oculata in which A. infesta was found. White arrows indicate the extent of spread of $A$. infesta. Shorter black arrow pointing towards the fracture surface of 1 B, D and E, longer black arrow towards the surface of C; (B) overview over fracture surface with $A$. infesta tissue (upper half); (C) empty 
Table 2. Dimensions of Aka spp. oxeas presumed fully-formed.

\begin{tabular}{lcc}
\hline Species & Minimum oxea width $(\mu \mathrm{m})$ & Maximum oxea length: width ratio \\
\hline A. brevitubulata (holotype) & 4.5 & 34 \\
A. cachacrouense (holotype) & 6.5 & 32 \\
A. coralliphaga forma typica (holotype) & 6.0 & 24 \\
A. infesta (ZMA POR 19927 and Johnson, 1899) & 6.5 & 24 \\
A. insidiosa (Johnson, 1899) & 7.0 & 26 \\
A. labyrinthica (holotype) & 8.0 & 14 \\
A. maldiviensis (paratype) & 5.0 & 28 \\
A. minuta (MRAC 1466) & 4.5 & 28 \\
A. mucosa (holotype) & 9.5 & 22 \\
A. mucosa (from the Great Barrier Reef) & 7.0 & 28 \\
A. nodosa (holotype) & 10.5 & 18 \\
A. paratypica (QM G32242) & 5.5 & 26 \\
A. rodens (Johnson, 1899) & 3.5 & 28 \\
A. siphona (USNM 24107) & 3.0 & 54 \\
A. xamaycaense (holotype) & 4.5 & 28 \\
\hline
\end{tabular}

restricted to the Indo-Pacific (ARKive and UNEP-WCMC webpages) and is phototrophic and thus occurs in shallow water. Nevertheless, 'A. labyrinthica' is presently only known from the Mediterranean Sea and the North Atlantic and has been described from as deep as $880 \mathrm{~m}$ (Table 1). This distributional discrepancy has largely been overlooked. To date, it has generally been assumed that Hancock's types mostly stem from Great Britain (e.g. Desqueyroux-Faúndez \& Valentine, 2002), and the occurrence of A. labyrinthica in the Mediterranean has not been questioned before.

In the present publication we attempt to resolve the identity for some of the Mediterranean and Atlantic samples of 'A. labyrinthica', to provide some tentative synonyms and to deal with related taxonomic issues. New sample material of Mediterranean Aka was made available by M. Taviani (ISMAR, GNR, Bologna, Italy), allowing us to make a well-founded taxonomic decision. As the only available historical type series (Hancock, 1849) is merely represented by slide preparations, we strongly relied on oxea biometric data, which yielded some interesting results that appear to have general value for the genus and will help in future comparisons.

\section{MATERIALS AND METHODS}

Fresh sample material was collected during the CORSARO cruise (26 April-6 May 2006) on the RV 'Urania' as part of the programmes ESF Euromargins Moundforce and EU HERMES. A trawl on the Apulian shelf at Santa Maria di Leuca, at the 'heel' of southern Italy (Ionian Sea, Mediterranean, trawl start: $39^{\circ} 37.48^{\prime} \mathrm{N}$ $18^{\circ} 39.00^{\prime} \mathrm{E}$ in $671 \mathrm{~m}$; end: $39^{\circ} 38.01^{\prime} \mathrm{N} 18^{\circ} 40.38^{\prime} \mathrm{E}$ in $679 \mathrm{~m}$ ) yielded a dead specimen of Madrepora oculata Linnaeus, 1758 (Figure 1A), in which one specimen of $A k a$ was found (Figure $1 \mathrm{~B}, \mathrm{C})$. The sample was fixed in $70 \%$ alcohol. We lodged it with the Zoological Museum, Amsterdam, access no. ZMA POR 19972.

Museums and colleagues provided further material: slide preparations of $A k a$ spp., tissue fragments and photographic material of $A k a$ oxeas with known scale (sample number acronyms as follows: BC-Barbara Calcinai's personal collection, CS — Christine Schönberg's personal collection, DNBE_-sampled and/or determined by Nicole BouryEsnault, DT—sampled and/or determined by Emile Topsent, HMN-Hancock Museum, Newcastle upon Tyne, LPBLittle Pioneer Bay, MD-Maldives, MNHN-National Museum of Natural History, Paris, MRAC-Royal Africa Museum, Tervuren, MSNG-Museum of Natural History, Genova, QM-Queensland Museum, Brisbane, USNMAmerican Museum of Natural History, Washington, ZMA POR-Porifera collection of the Zoologic Museum, Amsterdam).

Spicule preparations were made by digesting sponge tissue in heated, concentrated nitric acid $\left(60-70^{\circ} \mathrm{C}\right)$. Freed spicules were washed in distilled water and dehydrated in ethanol. The spicule-ethanol suspension was burnt on the microscope slide and mounted with Eukitt (Riedel de Haën, Seelze, Germany). Arrangement of spicules in the new

cavity that contained $A$. infesta tissue and matches upper half of $\mathrm{B}$; (D) close-up of $A$. infesta tissue. In the lower part of the photograph the tissue is shrinking back from the substrate; (E) spicule arrangement in a substrate canal, very close to the surface (upper left corner); detail of C, upper part; (F) tissue-spicule ring marking the site of a papillar structure, probably exhalant, on smallest fragment of Madrepora; $(\mathrm{G})$ minute fistule on short stem, widening at the top, on smallest fragment of Madrepora; $(\mathrm{H}-\mathrm{J})$ pluck-squeeze preparations of tissue; $(\mathrm{H})$ choanosomal tissue with loose and unordered arrangement of oxeas; (I) choanosomal tissue with loose arrangement of oxeas in parallel to each other; $(\mathrm{J})$ fragment of papillar ring, clearly showing the layered arrangement of densely-packed oxeas at right angle to each other; (K) SEM photograph of papillar fragment in which the lower layer of spicules would correspond with the outer layer of the minute fistule or papilla; $(\mathrm{L}-\mathrm{M})$ distribution and size of substrate pores made by $A$. infesta. A colour version of this figure is available at doi: 10.1594/PANGAEA.658949—-further details. 
Table 3. Aka spp. examined, together with respective sample information, sorted by name on sample label. The last column provides the last six digits of doi numbers at PANGAEA ${ }^{\circledR}$ for further sample information and data derived from the present study (doi: 10.1594/PANGAEA.xxxxxx). The respective numbers refer to the following parameters: $R D$, raw data of the spicule dimensions length, width, length:width ratio, angle; BS, basic statistics of the above spicule dimensions; FD, frequency distributions of the above spicule dimensions.

\begin{tabular}{|c|c|c|c|}
\hline Name of sample & Sample number & Sample site & $\begin{array}{l}\text { Last six digits for links to } \\
\text { PANGAEA }^{\circledR} \text { for further } \\
\text { sample information }\end{array}$ \\
\hline Aka brevitubulata & YPM 8717, holotype & Discovery Bay, Jamaica, Caribbean; 15 m & $\begin{array}{l}\text { RD: } 658959 \\
\text { BS: } 659037 \\
\text { FD: } 659065\end{array}$ \\
\hline Siphonodictyon cachacrouense & USNM 24094, holotype & Scotts Head Bay, Dominica, Caribbean; 35 m & $\begin{array}{l}\text { RD: } 658971 \\
\text { BS: } 659049 \\
\text { FD: } 659077\end{array}$ \\
\hline $\begin{array}{l}\text { Siphonodictyon coralliphagum } \\
\text { forma typica }\end{array}$ & USNM 24095, holotype & Discovery Bay, Jamaica, Caribbean; 25 m & $\begin{array}{l}\text { RD: } 658972 \\
\text { BS: } 659050 \\
\text { FD: } 659078\end{array}$ \\
\hline Acca infesta & $\begin{array}{l}\text { Figure } 4 \text { in Johnson's } \\
\text { publication }\end{array}$ & Madeira, North Atlantic; 'from deep water' & $\begin{array}{l}\text { RD: } 658975 \\
\text { BS: } 659053 \\
\text { FD: } 659081\end{array}$ \\
\hline $\begin{array}{l}\text { Aka infesta } \\
\text { (was measured twice) }\end{array}$ & ZMA POR 19927 & $\begin{array}{l}\text { Apulian Shelf, Ionian Sea, Mediterranean; } \\
671-679 \mathrm{~m}\end{array}$ & $\begin{array}{l}\text { RD: } 658942 \text { and } 658984 \\
\text { BS: } 658949 \text { and } 659062 \\
\text { FD: } 658948 \text { and } 659090 \\
\text { coloured image at } 658942 \\
\text { - further information }\end{array}$ \\
\hline Aka infesta & ZMA POR 05194 & Tenerife, Canary Islands, North Atlantic; 3 m & $\begin{array}{l}\text { RD: } 658974 \\
\text { BS: } 659052 \\
\text { FD: } 659080\end{array}$ \\
\hline Acca insidiosa & $\begin{array}{l}\text { Figure } 1 \text { in Johnson's } \\
\text { publication }\end{array}$ & Madeira, North Atlantic; 'from deep water' & $\begin{array}{l}\text { RD: } 658976 \\
\text { BS: } 659054 \\
\text { FD: } 659082\end{array}$ \\
\hline Aka labyrinthica & $\begin{array}{l}\text { CS collection, no } \\
\text { number, 'Portofino' }\end{array}$ & $\begin{array}{l}\text { Portofino, Ligurian Sea, Mediterranean; } \\
\text { unknown depth }\end{array}$ & $\begin{array}{l}\text { RD: } 658970 \\
\text { BS: } 659048 \\
\text { FD: } 659076\end{array}$ \\
\hline Aka labyrinthica & $\begin{array}{l}\text { BC collection, no number, } \\
\text { 'Costa Brava' }\end{array}$ & $\begin{array}{l}\text { Costa Brava, Spain, Mediterranean; } \\
\text { unknown depth }\end{array}$ & $\begin{array}{l}\text { RD: } 658968 \\
\text { BS: } 659046 \\
\text { FD: } 659074\end{array}$ \\
\hline $\begin{array}{l}\text { Cliona labyrinthica } \\
\text { (contained two kinds } \\
\text { of oxeas typical for } A k a \text {; } \\
\text { the doi digits on the left } \\
\text { refer to original holotype } \\
\text { material) }\end{array}$ & $\begin{array}{l}\text { Photographs of spicules } \\
\text { of holotype HMN } \\
4.15 .45-4.15 .48 \\
\text { (Hancock's no. } 30 \\
\text { for all slides) }\end{array}$ & $\begin{array}{l}\text { In Tridacna gigas }=\text { Indo-Pacific, } \\
\text { photic zone }\end{array}$ & $\begin{array}{l}\text { RD: } 658977 \text { and } 658961 \\
\text { BS: } 659055 \text { and } 659039 \\
\text { FD: } 659083 \text { and } 659067\end{array}$ \\
\hline Cliona labyrinthica & MNHN DNBE 711 & Unknown sample location and depth & $\begin{array}{l}\text { RD: } 658969 \\
\text { BS: } 659047 \\
\text { FD: } 659075\end{array}$ \\
\hline Cliona labyrinthica & MNHN DT 875 & Azores, North Atlantic; $880 \mathrm{~m}$ & $\begin{array}{l}\text { RD: } 658967 \\
\text { BS: } 659045 \\
\text { FD: } 659073\end{array}$ \\
\hline Cliona labyrinthica & MNHN DT 2423 & $\begin{array}{l}\text { Banyuls, Gulf of Lion, Mediterranean; } \\
\text { unknown depth }\end{array}$ & $\begin{array}{l}\text { RD: } 658973 \\
\text { BS: } 659051 \\
\text { FD: } 659079\end{array}$ \\
\hline Cliona labyrinthica & MNHN DT 2521 & $\begin{array}{l}\text { In Tridacna gigas }=\text { Indo-Pacific, } \\
\text { photic zone }\end{array}$ & $\begin{array}{l}\text { RD: } 658966 \\
\text { BS: } 659044 \\
\text { FD: } 659072\end{array}$ \\
\hline Aka maldiviensis & $\begin{array}{l}\text { BC collection MD } 101 \text {, } \\
\text { spicule preparation of } \\
\text { paratype }\end{array}$ & Kuda Rah, Maldives, Indian Ocean; 12 m & $\begin{array}{l}\text { RD: } 658978 \\
\text { BS: } 659056 \\
\text { FD: } 659084\end{array}$ \\
\hline Aka minuta & MRAC 1466 & $\begin{array}{l}\text { Inhaca, Mozambique, Indian Ocean; } \\
\text { unknown depth }\end{array}$ & $\begin{array}{l}\text { RD: } 658981 \\
\text { BS: } 659059 \\
\text { FD: } 659087\end{array}$ \\
\hline
\end{tabular}


Cliona nodosa

Cliona nodosa

Cliona nodosa

Aka paratypica

Acca rodens

Siphonodictyon siphonum

Siphonodictyon xamaycaense
Photographs of spicules of holotype HMN 4.16.11-4.16.13

(Hancock's no. 24 for all slides)

MNHN DT 2534

MNHN DT 2533

GM G322242

Figure 2 in Johnson's publication

USNM 24107

MSNG 47907, holotype
Little Pioneer Bay, Orpheus Island, Palm Island Group, central Great Barrier Reef, western Pacific; $1 \mathrm{~m}$

Little Pioneer Bay, Orpheus Island, Palm Island Group, central Great Barrier Reef, western Pacific; $3 \mathrm{~m}$

Little Pioneer Bay, Orpheus Island, Palm Island Group, central Great Barrier Reef, western Pacific; $3 \mathrm{~m}$

Iwayama Bay, Palau, Pacific; 0.9-6 m

In Tridacna gigas=Indo-Pacific, photic zone

Pointe-à-Pître, Guadeloupe, Caribbean, unknown depth

unknown sample location and depth ('in polypier')

Little Pioneer Bay, Orpheus Island, Palm Island Group, central Great Barrier Reef, western Pacific; $1.7 \mathrm{~m}$

Madeira, North Atlantic; 'from deep water'

End of Turtle Rocks, Bimini, Bahamas, North Atlantic, $1 \mathrm{~m}$

Jamaica, Caribbean; 40-45 m
RD: 658982

BS: 659060

FD: 659088

RD: 658958

BS: 651936

FD: 659064

RD: 658957

BS: 659035

FD: 659063

RD: 658983

BS: 659061

FD: 659089

RD: 658960

BS: 659038

FD: 659066

RD: 658979

BS: 659057

FD: 659085

RD: 658980

BS: 659058

FD: 659086

RD: 658962

BS: 659040

FD: 659068

RD: 658963

BS: 659041

FD: 659069

RD: 658964

BS: 659042

FD: 659070

RD: 658965

BS: 659043

FD: 659071 sample was viewed in pluck preparations mounted with Gel/ Mount (Biomeda, USA).

Biometric studies on acid-cleaned spicules of all available species were conducted under a Leica DMBL phase contrast microscope with micrometer eyepiece $(\times 2000$ maximum magnification). Per slide, the first 50 oxeas along a randomly chosen path were measured as long as they were possible to focus, undamaged and not significantly malformed. We recorded their maximum length, maximum width and the inner angle (from the central point of the spicule to the actine points, with the 'central' point being slightly displaced towards one tip in asymmetrical forms; using the software analySIS 3.2 and a ColorView I digital camera). The same measurements were conducted with a ruler on figures where only photographs or drawings were available. From the first set of measurements and per sample, frequency distributions were plotted to assess the occurrence of immature spicules. Where histograms for spicule width and length:width ratios were clearly bimodal with one maximum in the thin range for width or one in the large range for the ratio, we omitted all measurements of the slimmer spicules and replaced missing values with secondary measurements of a random selection of spicules presumed mature. We accepted spicules as mature at a minimum width and maximum length:width ratio as indicated in Table 2. Length:width ratios were calculated (Rützler, 1971), and a biometric index was formed, dividing the ratio by the inner angle of oxea. All obtained parameters were subjected to biometric studies, including frequency distributions (doi: 10.1594/PANGAEA.659091). Data were further compared with parametric statistics (MANOVA and Sheffé's post hoc tests for each parameter). Finally, counts of significant differences $(P<0.05)$ between pairwise comparisons of specimens were evaluated to detect putative conspecific samples.

For the description of our own Mediterranean sample, bioerosion traces were examined under a Wild Heerbrugg dissecting stereoscope and with scanning electron microscopy (SEM). The SEM was conducted on substrate fragments that were cleaned in desalinated water (Zeiss DMS 940) and on trace casts after vacuum embedding (CamScan ${ }^{\circledR}$; Beuck \& Freiwald, 2005). Embedded material was cut in parallel to the growth axis of the coral, and the carbonate substrate was dissolved in $10 \% \mathrm{CHOOH}$ to free the casts. After obtaining morphological data on the new sample, we identified it by consulting respective literature and other samples as far as available. Comparison with Johnson's (1899) material was difficult, as neither specimens nor slides exist. We measured spicules from the figures of his publication. As they appear to be drawings, oxea lengths are probably more reliable than the widths and length:width ratios. We did not use 
respective angles, because they are unlikely to be accurate in drawings.

At the end of our study we found ourselves with a good reference collection of $A k a$ spicule slides and photographs, including some species that are not easily accessed. We created a database on spicule parameters through PANGAEA ${ }^{\circledR}$ (doi: 10.1594/PANGAEA.659091) that will also be used in forthcoming publications and will later be supplied with additional data and figures (C.H.L. Schönberg, unpublished data), in review and related publications). This database will represent a virtual reference collection for other users.

\section{SYSTEMATICS}

Class DEMOSPONGIAE Sollas, 1885

Order HAPLOSCLERIDA Topsent, 1928

Suborder PETROSINA Boury-Esnault \& van Beveren, 1982

Family PHLOEODICTYIDAE Carter, 1882

Genus Aka (Johnson, 1899 as Acca) de Laubenfels, 1936 Aka infesta (Johnson, 1899)

(Figures 1-4)

Synonymies: Table 1

\section{Material examined}

The material we considered is listed in Table 3. Of this, 25 different specimens were suitable for biometric studies of the spicules. More detailed sample information for each specimen is available at PANGAEA ${ }^{\circledR}$ (see doi numbers in Table 3).

\section{Diagnosis for Aka infesta}

Aka with robust, well-silicified oxeas, only rarely with open tips or corroded axial canals (Figure 2). Oxea tips regulartapering in appearance, usually very sharply pointed and without easily discernible telescoping or tendencies for mamillate points. Spicular arrangement in endosome confused, ordered and layered in minute fistules. Mucoid. Multicamerate erosion.

\section{Description of Aka infesta from the Ionian Sea specimen ZMA POR 19972}

Colour and morphology: endosome light moss-green in ethanol (Royal Horticultural Society colour chart: RHS 152B; coloured images at doi: 10.1594/PANGAEA.658942). Fistular structures and drying endosomal tissue ochreyellow (RHS 153C to 160B). Alcohol-preserved endosome slightly rubbery, shrinking away from erosion chamber walls when drying, leaving latter clean or adhering with minute string-like tissue extensions that eventually break (Figure 1D). Papillae near invisible, merely coating inner walls of canals, often not quite reaching substrate surface (Figure 1E). Larger openings with mere tissue-and-spicule rings, more or less flush with substrate surface (Figure 1F). Where present, fistules minute, brittle and delicate, one fistule observed with short stem of 2-3 mm in height, thin-walled, with widening apical part (Figure 1G). In papillar tissue rings and minifistules surface spicules arranged in parallel and following outer curvature of papillae or fistules, i.e. following superficial ring-like arrangement without discernible hispidity. Where tissue observed in substrate canals leading outward, spicules in dense aggregation, oriented in parallel to canal wall (Figures 1E \& 3A). Choanosomal spicule arrangement loose

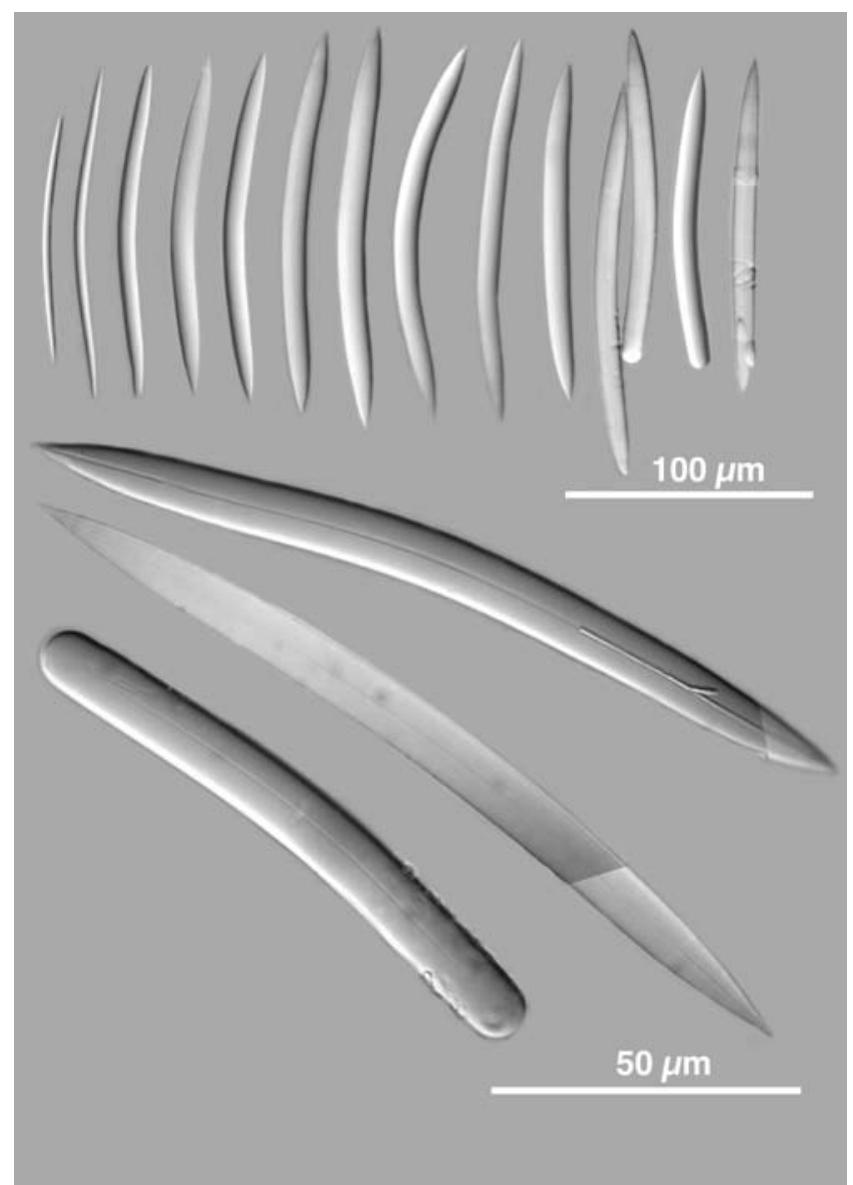

Figure 2. Oxeas of Aka infesta specimen ZMA POR 19927 with acerate to long-acerate tips and well-silicified axial regions. Upper row: first three oxeas immature elements. Oxeas in the middle of the row slightly biangular. Last oxea malformed with branches and tylar areas, second and third last with stylar modifications. Magnified oxeas below: uppermost oxea with enlarged axial canal, second oxea with drawn-out long-acerate tips, lowermost strongylar modification.

and largely unordered (Figure $1 \mathrm{H}$ ), in some areas oxeas loosely aligned in parallel, reminiscent of rungs of a ladder (Figure 1I). Oxeas in papillar structures closely packed and arranged in parallel, clearly displaying two layers with oxeas oriented at right angle to each other (Figure $1 \mathrm{~J}, \mathrm{~K}$ ).

Spicules: only one spicule type and rare derivates (latter less than $4 \%$ of all observed spicules, see Table 4). Megascleres smooth, for $A k a$ comparatively robust oxeas (Figure 2). Most with longish, almost conical-hastate to asymmetricalacerate tips, usually very sharply pointed, but occasionally slightly rounded in thicker oxeas and rarely very, very subtly stepped. Shafts usually softly curved, some shafts centrally slightly angulate. Occasional occurrence of very slightly asymmetrical oxeas (more common in straighter forms; Figure 2, 5th last oxea) and very slightly biangulate oxeas (more common in oxeas with more pronounced curvature; Figure 2, 8th and 9th oxea). Mean dimensions for mature, endosomal oxeas: $149 \mu \mathrm{m}$ in length, $9 \mu \mathrm{m}$ in width, mean length:width ratio 16 , mean angle of oxea curvature $168^{\circ}$ (N=50), immature oxeas easily recognizable by width mostly under $5 \mu \mathrm{m}$ (Figures $2 \& 4$ ). Mean dimensions of immature oxeas $129 \mu \mathrm{m}$ in length, $4 \mu \mathrm{m}$ in width, mean length:width 

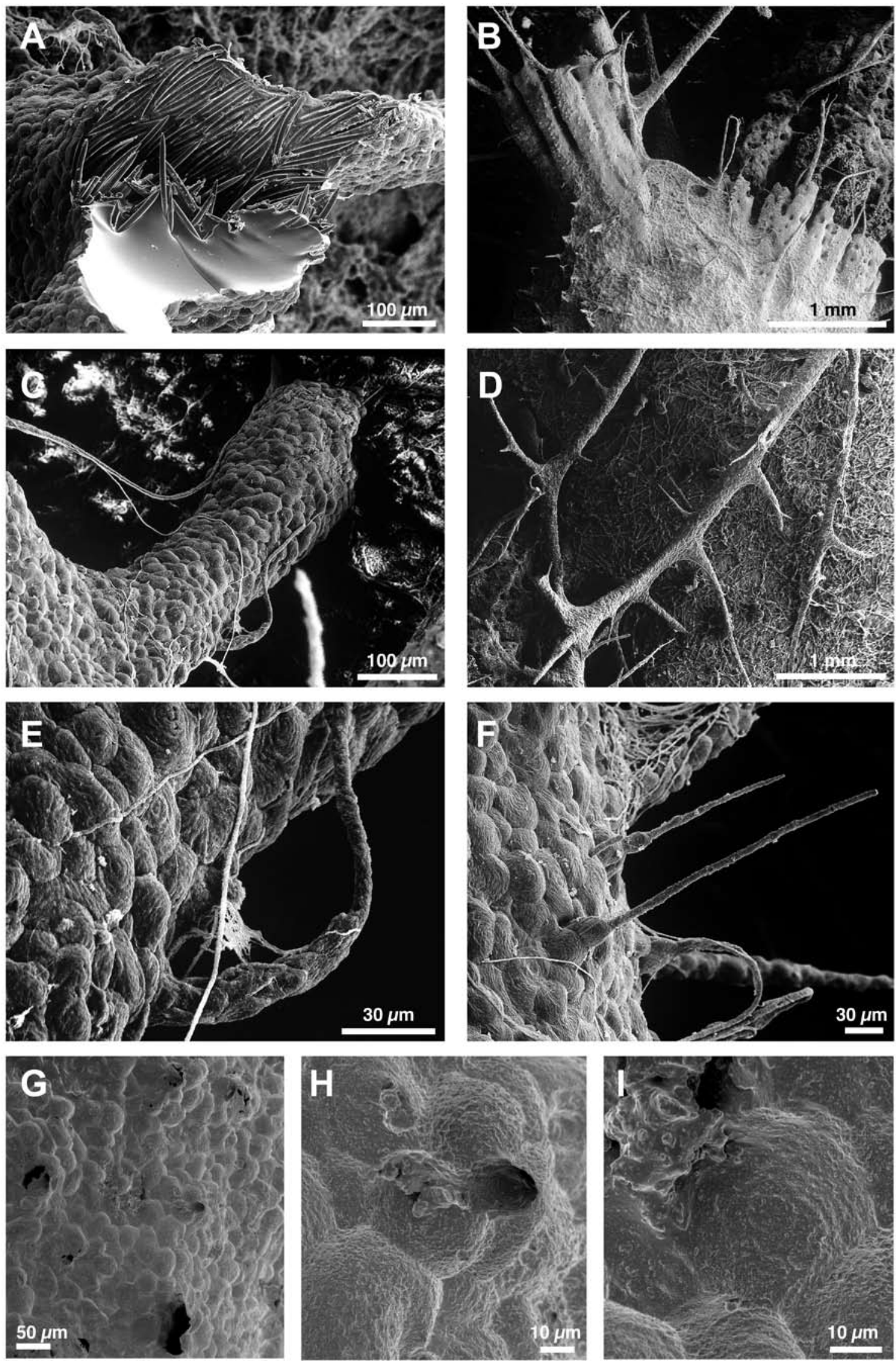

Figure 3. Erosion traces of Aka infesta ZMA POR 19927 in Madrepora oculata. (A-F) SEMs of trace casts; (G-I) SEMs of traces. (A) Chamber narrowing into connecting canal, partly chipped to reveal spicules inside; (B) erosion chamber merging with septal lumina of corallites of M. oculata; $(\mathrm{C})$ apertural canal connecting erosion chamber with substrate surface; (D) pioneer threads transversing the substrate, with antler-like branching; (E) whip-like extension on apertural canal (enlargement of C); note comparatively oval form of scars on extension and ring-like sculpturing on scars on connecting canal; $(\mathrm{F})$ very fine radiating extensions without sculpturing of scars; $(\mathrm{G})$ distribution of scars and unprotected openings into chamber lumen; $(\mathrm{H})$ scars and a minute aperture leading outwards; (I) concentric rings in the scars are very faint and often invisible. 
Table 4. Spicule dimensions of Aka infesta from the Ionian Sea, ZMA POR 19927. Dimensions are given as minimum-mean-maximum (plain print), standard deviation/coefficient of variance (italics). Please note very small sample size ( $\mathcal{N})$ for immature oxeas and styles and that only one strongyle was found.

\begin{tabular}{|c|c|c|c|c|c|c|}
\hline & \multicolumn{4}{|c|}{ Spicule dimensions } & \multicolumn{2}{|c|}{ Frequencies } \\
\hline & Length $(\mu \mathrm{m})$ & Width $(\mu \mathrm{m})$ & Length:width ratio & Inner angle $\left(^{\circ}\right)$ & $\mathrm{N}$ & $\%$ \\
\hline Mature oxeas & $\begin{array}{c}130.0-\mathbf{1 4 9 . 3}-168.8 \\
8.1 / 5.4\end{array}$ & $\begin{array}{c}6.5-9.3-11.3 \\
1.0 / 10.8\end{array}$ & $\begin{array}{c}13.3-\mathbf{- 1 6 . 1}-20.4 \\
1.8 / 11.2\end{array}$ & $\begin{array}{c}158.1-\mathbf{1 6 7 . 7}-178.0 \\
4.0 / 2.4\end{array}$ & 50 & 89.0 \\
\hline Immature oxeas & $\begin{array}{c}120.0-\mathbf{1 2 8 . 8}-135.0 \\
7.5 / 5.8\end{array}$ & $\begin{array}{c}3.8-\mathbf{4 . 4}-4.8 \\
0.4 / 9.1\end{array}$ & $\begin{array}{c}27.8-\mathbf{2 9 . 5}-32.0 \\
1.9 / 6.4\end{array}$ & $\begin{array}{c}167.3-\mathbf{1 6 8 . 3}-170.1 \\
1.2 / 0.7\end{array}$ & 4 & 7.3 \\
\hline Styles & $\begin{array}{c}120.0-\mathbf{1 2 1 . 3}-122.5 \\
1.8 / 1.5\end{array}$ & $\begin{array}{c}10.0-\mathbf{1 0 . 0}-10.0 \\
0.0 / 0.0\end{array}$ & $\begin{array}{c}12.0-\mathbf{1 2 . 1}-12.3, \\
0.2 / 1.7\end{array}$ & $\begin{array}{c}164.8-\mathbf{1 6 7 . 8}-170.7 \\
4.2 / 2.5\end{array}$ & 2 & 2.4 \\
\hline Strongyle & 100 & 11.3 & 8.9 & 166.6 & 1 & 1.2 \\
\hline
\end{tabular}

ratio 30 , mean angle of oxea curvature $168^{\circ}(\mathrm{N}=4 ; 7 \%$ of the amount of all observed spicules; Table 4). Oxea length and width very uniform (Figure 4). Rare derivates in form of styles (2\%, mean length $121 \mu \mathrm{m}$, mean width $10 \mu \mathrm{m}$, mean angle of curvature $168^{\circ}, \mathrm{N}=2$; Figure 2; Table 4) and strongyles (1\%, only one found: $100 \mu \mathrm{m}$ long, $11 \mu \mathrm{m}$ wide, angle of curvature $167^{\circ}$; Figure 2; Table 4). Rare malformations with very finely split axial threads and points, resulting in point duplication or branches (Figure 2, last oxea). Axial thread only faintly visible, most oxeas very well silicified (Figure 2).

Erosion patterns: multicamerate erosion traces. Big, rounded to lobate-elongated chambers following the branches of Madrepora oculata, occasionally merging with lumina of corallites (Figures 1B,C \& 3B). Mean maximum diameter of erosion chambers $4.9 \mathrm{~mm}(\mathrm{~N}=10)$. Minute canals of 60 to $180 \mu \mathrm{m}$ in diameter, in exceptions $400 \mu \mathrm{m}$ in diameter (Figure 3G), connecting chambers and leading to surface pores. Externally, only minute pores visible (Figure $1 \mathrm{~L}, \mathrm{M})$. Smaller ones about $0.2-0.4$ (inhalants?), larger ones about $0.7 \mathrm{~mm}$ in diameter (exhalants?). Pioneer threads with antler-like branches (Figure 3D). Canal and chamber walls with numerous minute, unbranching apertural extensions radiating out into substrate, as typical for $A k a$ (Figure 3E). Extensions 4.5-7.2 $\mu \mathrm{m}$ in diameter at bases. Smaller extensions without sculpturing of erosion scars (Figure 3F). Unable to locate dome-shaped sieves formed by remaining substrate material at endpoints of canals from surface entering erosion chambers (Figure 3A\&G), as known for other species of $A k a$. Erosion scars in main chambers 15-60 $\mu \mathrm{m}$ in diameter (usually $45 \mu \mathrm{m}$ ), shallow, cup-shaped, oval to circular (Figure 3C\&E,F). Scars of pioneer threads 25-35 $\mu \mathrm{m}$, and of apertural extensions $\leq 15 \mu \mathrm{m}$, elongated (Figure 3E). Micropatterns in scars very faint, resembling circular grooves (Figure 3G\&I), but smooth scars dominate (Figure 3I). Micropatterns occasionally more pronounced in trace casts (Figure 3E).

\section{Remarks}

The present sample from the Ionian Sea was identified as Aka infesta (Johnson, 1899). Four species of $A k a$ were quickly discounted as possibilities, as their oxeas and fistules are too large, they are known for their mostly unicamerate erosion and they occur in disparate areas to the present samples (Caribbean and Pacific): A. cachacrouense, A. coralliphaga, A. mucosa and A. siphona (Rützler, 1971). Aka nodosa has too long oxeas with an angular, markedly stronger bend than in the present sample. Aka densa also has too large oxeas (C.H.L. Schönberg, preliminary and unpublished data). In contrast, oxeas of the following species are too short to match the present sample and except for $A$. rodens occur in disparate regions: $A$. labyrinthica, $A$. minuta, $A$. rodens and $A$. xamaycaense (Indo-Pacific and Caribbean, A. rodens North Atlantic; Hancock, 1849; Johnson, 1899; Thomas, 1972; PulitzerFinali, 1986). Aka terebrans, A. brevitubulata, A. maldiviensis and $A$. paratypica have a similar mean oxea length compared to the present sample, but much slimmer oxeas, and the latter three have larger fistules and unicamerate erosion, and all occur at disparate sample sites (Caribbean and Indo-Pacific; Pang, 1973; Fromont, 1993; Calcinai et al., 2000b; C.H.L. Schönberg, preliminary and unpublished data). Aka paratypica also has dome-shaped structures of remaining substrate in the erosion chambers (Schönberg \& Tapanila, 2006) that were not found in the present sample. Remaining species have similar oxea dimensions compared to our sample. However, except for $A$. infesta they were dismissed on the following grounds. Aka diagonoxea has too long fistules $(2-5 \mathrm{~cm})$, too large chambers ( $2 \mathrm{~cm}$ in diameter), has dome-shaped structures in the erosion chambers and occurs in the Indian Ocean (Thomas, 1972). Aka insidiosa's surface erosion pores appear to be larger in diameter than in the present sample, and we were unable to locate skeletal arrangements as pictured in Johnson's (1899) figure 1. In contrast, Johnson's (1899) figure 4 for $A$. infesta is remarkably similar to our findings for the present sample. Also, the stout, robust appearance of the spicules in Johnson's figure 4 resembles what we observed for ZMA POR 19972. Despite the possible difference in colour and the slightly different sample region (Johnson: pale yellow in life and North Atlantic, ZMA POR 19972: light moss-green in ethanol and Mediterranean), characters of Johnson's (1899) A. infesta are the most similar to those of the present sample, and we identified it accordingly.

Some of the decisions for excluding all of the above species but $A$. infesta were largely based on spicule dimensions that may vary (Wiedenmayer, 1977; Schönberg \& Barthel, 1997; Uriz et al., 2003) or have previously been described with inadequate accuracy. Particularly where spicule width is involved (=strongly influenced by the occurrence of immature spicules), great care should be taken, especially as we have 

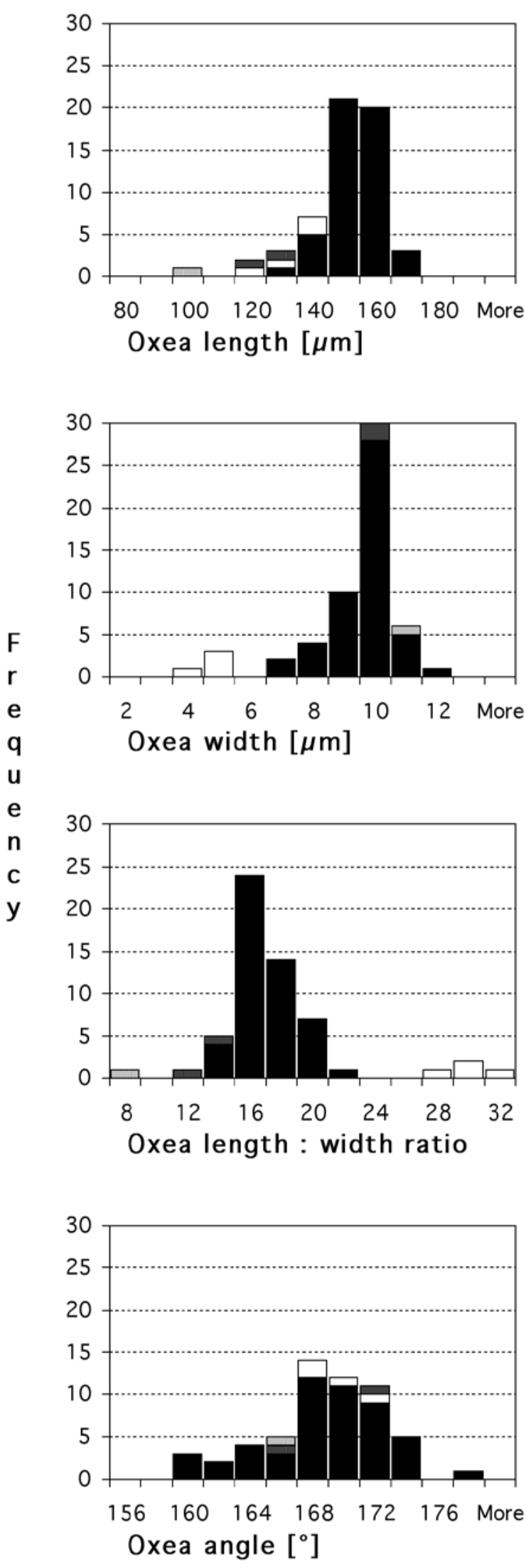

Figure 4. Frequency distributions of Aka infesta ZMA POR 19927 spicule dimensions in detail. (A) Spicule lengths; (B) spicule widths; (C) length:width ratio of spicules; (D) angle of spicules. Black bars, mature oxeas; white bars, immature oxeas; dark grey bars, styles; light grey bars, one sytrongyle. Total $\mathrm{N}=57$. no information about the historic author's methodological approaches. Nevertheless, the present samples match other descriptive characters given for $A$. infesta (Johnson, 1899) as well and at least slightly differ from those of the species listed above. Our decision is therefore the best presently possible. As it may still be possible that our material represents a new species, rather than $A$. infesta, we recommend confirmation of our findings with sample material from Madeira that should be lodged in a museum as neotype.

\section{RESULTS AND DISGUSSION}

Biometric comparisons of spicule characters of Aka spp.

Frequency distributions of oxea dimensions for all studied $A k a$ spp. yielded a good first impression of differences and similarities (doi: 10.1594/PANGAEA.659091). Aka chachacrouense and A. mucosa had extremely long oxeas with means around $200 \mu \mathrm{m}$. Another cluster of specimens shared very short oxeas between 90 and $130 \mu \mathrm{m}$ on average, which were comparable with those of $A$. labyrinthica: the Mediterranean samples from the Costa Brava and Portofino; samples from the Indo-Pacific and Caribbean including $A$. labyrinthica sensu Hancock (1849), A. minuta, A. xamaycaense, MNHN DT2521 and MNHN DT2534; and samples of unknown origin, MNHN DNBE711 and MNHN DT2533. We recognized some differences in their oxea forms and it was clear that this cluster still contained more than one species, but just using the histograms did not facilitate adequate discrimination, MNHN DT875 had by far the thickest oxeas with a mean of close to $14 \mu \mathrm{m}$, unparalleled by any other species studied here. The thinnest oxeas of species not belonging to the cluster mentioned above belonged to $A$. brevitubulata and $A$. siphona, which were very distinct. Oxea angles generally displayed nice, bell-shaped distributions that did not differ much between species, mostly with means of about 165 to and $170^{\circ}$. Aka xamaycaense, MNHN DT2534 and an unknown species in the $A$. labyrinthica type material had comparatively straight oxeas with angles of $>170^{\circ}$, whereas oxeas from A. coralliphaga, A. labyrinthica sensu Hancock (1849), Aka paratypica, ZMA POR 05194 and MNHN DT875 had a more pronounced curvature of $<164.5^{\circ}$.

Our raw and biometric data were lodged with PANGAEA ${ }^{\circledR}$ (see Table 3) so that researchers can download them for future investigations. Statistical comparisons should be conducted only with randomly selected, mature spicules, and sample sizes and tissue fractions should match between compared data sets. The perception of an angle can be biased in tissue preparations, and it is essential to make sure that spicules rest on the side when measuring.

All measured parameters were here subjected to statistics and significantly differed between our samples of $A k a$ spp. (overall $\mathrm{df}=125, P=0.0001$, MANOVA; $\mathrm{df}=25, P=0.0001$ for each separate dimension, length, width, angle, length:width ratio and oxea index). In a Scheffé's post hoc test, all samples were compared pairwise to investigate how well the present approach worked and whether conspecific material could be recognized in the sample pool, especially when focusing on the Mediterranean samples originally named 'labyrinthica'.

Spicule length and width of mature oxeas proved to be comparatively sensitive parameters when considered separately without regarding any other characters. They 
generated 84.3 and $79.7 \%$ significant and genuine differences between the studied sample pairs, respectively (Table 5). The angle of the oxea curvature by itself was the least helpful character and very uniform between the species: only $23.1 \%$ of the samples could be conclusively separated (Table 6). These results suggested that a combination of measured data was likely to be more useful. Working only with the oxea length:width ratio, the rate of significant differences was $75.4 \%$ (Table 6), i.e. still lower than when using either length or width. This was caused by joining different species that had the same oxea proportions, but still had different oxea lengths and widths. Using this ratio for taxonomic purposes may thus be hazardous, if this parameter is regarded as being superior to the others, but as additional character it can be useful (Rützler, 1971). Generating an oxea index and including the angle as well by dividing the length: width ratio by it, the significance rate reached only $73.2 \%$ (Table 7). Obviously, a different approach or an additional parameter was necessary. We tested categories of oxea tip form, roughly distinguishing between acerate (as in most Aka spp.), conical (as in sample ZMA POR 05194), conicalconcave (as e.g. in A. siphona) and rounded-mamillate (as in A. paratypica). Tip form by itself only separated $40.6 \%$ of the samples as distinct from each other (Table 7). After trying different combinations of the above parameters, we found that the most reliable results were obtained, when working with count matrices of pairwise differences for length, width and tip form, rather than with the ratios (reaching 96.4\%; Table 8). Oxea angle as additional information was helpful to stronger define a few differences and to separate a few samples that appeared to belong to difficult species (reaching $97.5 \%$ differences in our sample pool; Table 8).

With the latter approach, known identical and conspecific samples were recognized as the same thus validating the method (A. infesta, A. minuta, A. mucosa from the Great Barrier Reef; Table 8). The few other sample pairs grouping together will have to re-investigated in more detail for possible conspecifity (MNHN DT2533 and 'Portofino', MNHN DT2533 and MNHN DT2534, A. infesta and MNHN DT2423, MNHN DT2521 and 'Costa Brava', A. xamaycaense and MNHN DNBE 711; Table 8). Specimen pairs that are displayed with only one difference generally appear to be different species, but some cases will have to be studied in more detail as well. If specimen pairs only differed by oxea width, they may still be conspecific (e.g. holotype of $A$. mucosa and Great Barrier Reef $A$. mucosa). Even when using only mature oxeas width it is a comparatively variable character that could not be measured with as much accuracy as the other parameters.

The study yielded a surprising result concerning the type material for A. labyrinthica. There appeared to be at least two species of $A k a$ in the spicule preparation: (1) A. labyrinthica sensu Hancock (1849) with oxeas that somewhat resembled peeled bananas with short, acerate tips and soft, well-formed bends (Figure 5A); and (2) very straight oxeas that were slightly longer, but also thinner than in A. labyrinthica sensu Hancock (1849), and with comparatively longer tips (Figure 5B). It is presently unknown that any $A k a$ spp. possesses two clearly different spicule types, yet these two kinds of spicules differed visually and biometrically (Figure 5; Tables 5-8). As
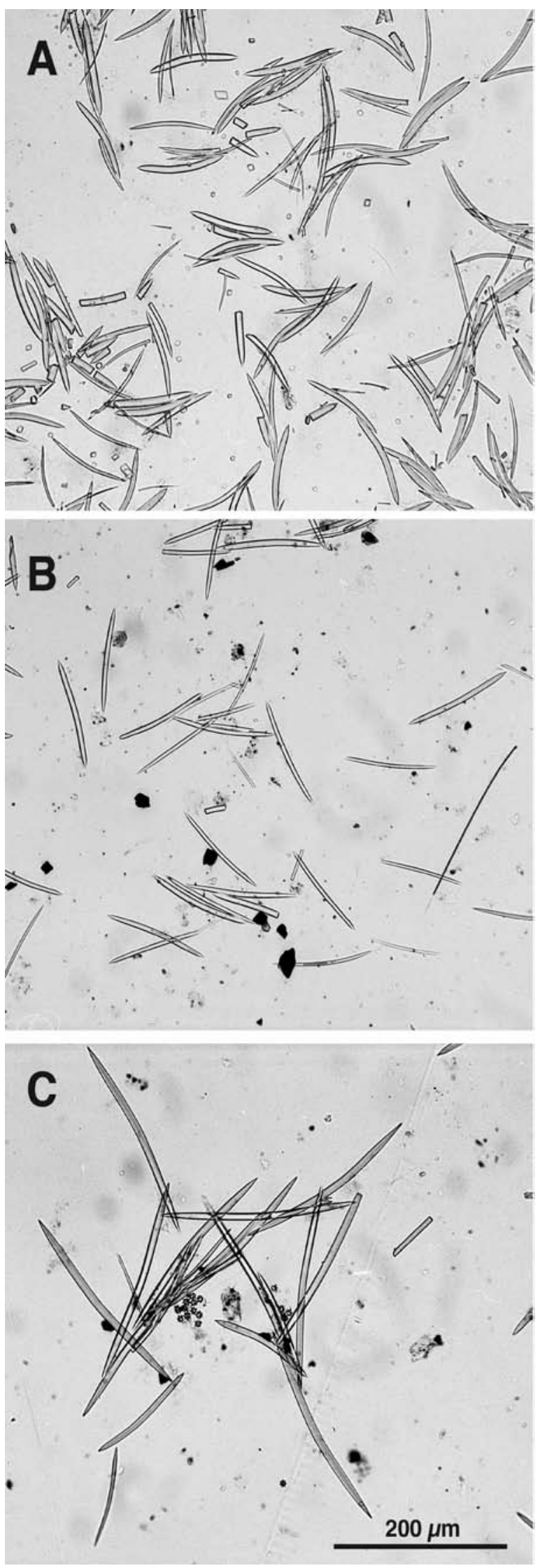

Figure 5. Spicule slide preparations of Hancock's (1849) Aka labyrinthica type material. (A) The stout oxeas of $A$. labyrinthica sensu stricto; (B) the second kind of $A k a$ oxeas in the type material, which differ from $A$. labyrinthica oxeas by their longer shafts and their straight form; $(\mathrm{C})$ a third type of oxeas in the type material is unlikely to belong to a third species of $A k a$ and is here regarded as contamination. The scale is the same for $\mathrm{A}-\mathrm{C}$. 


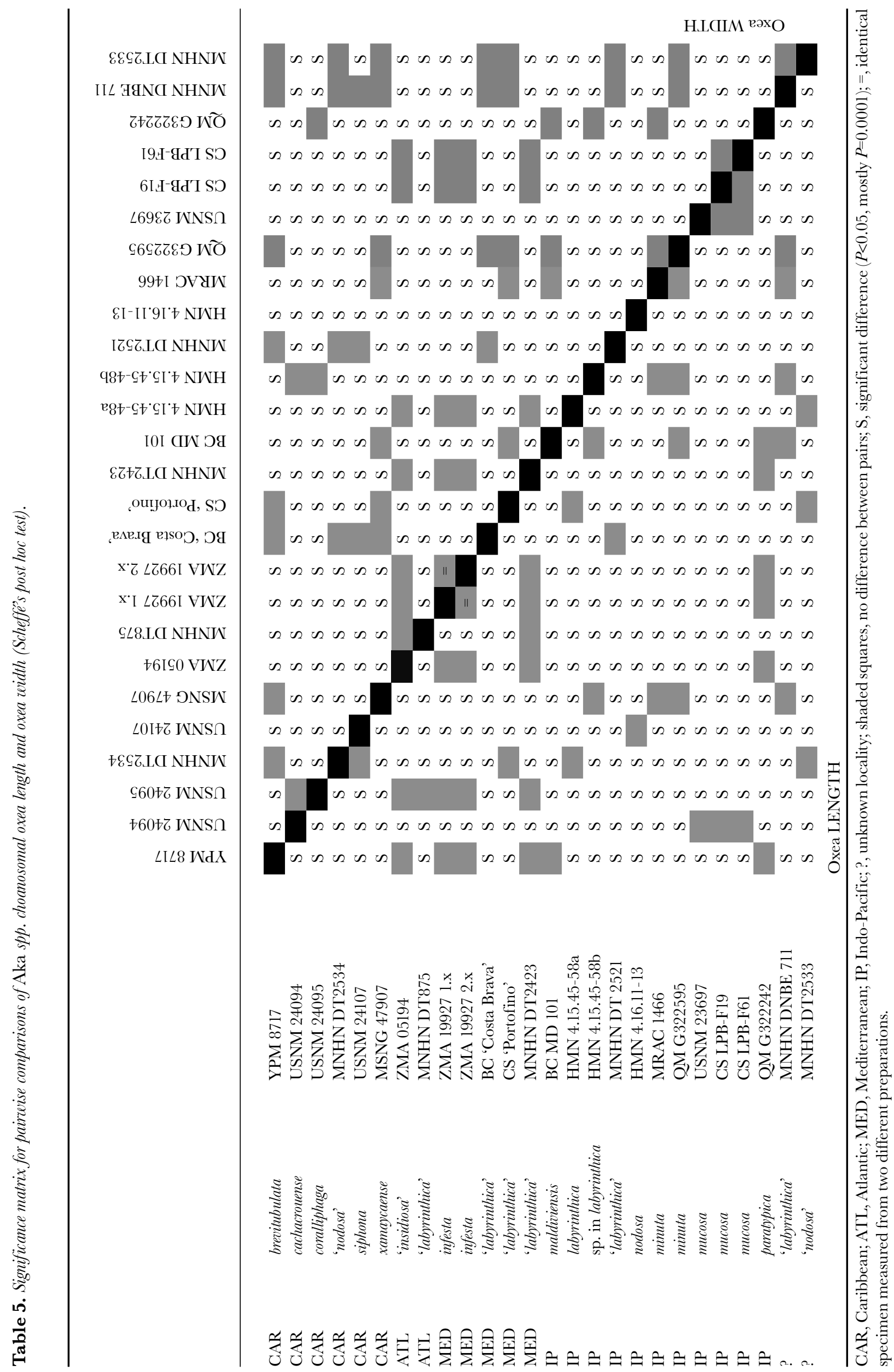




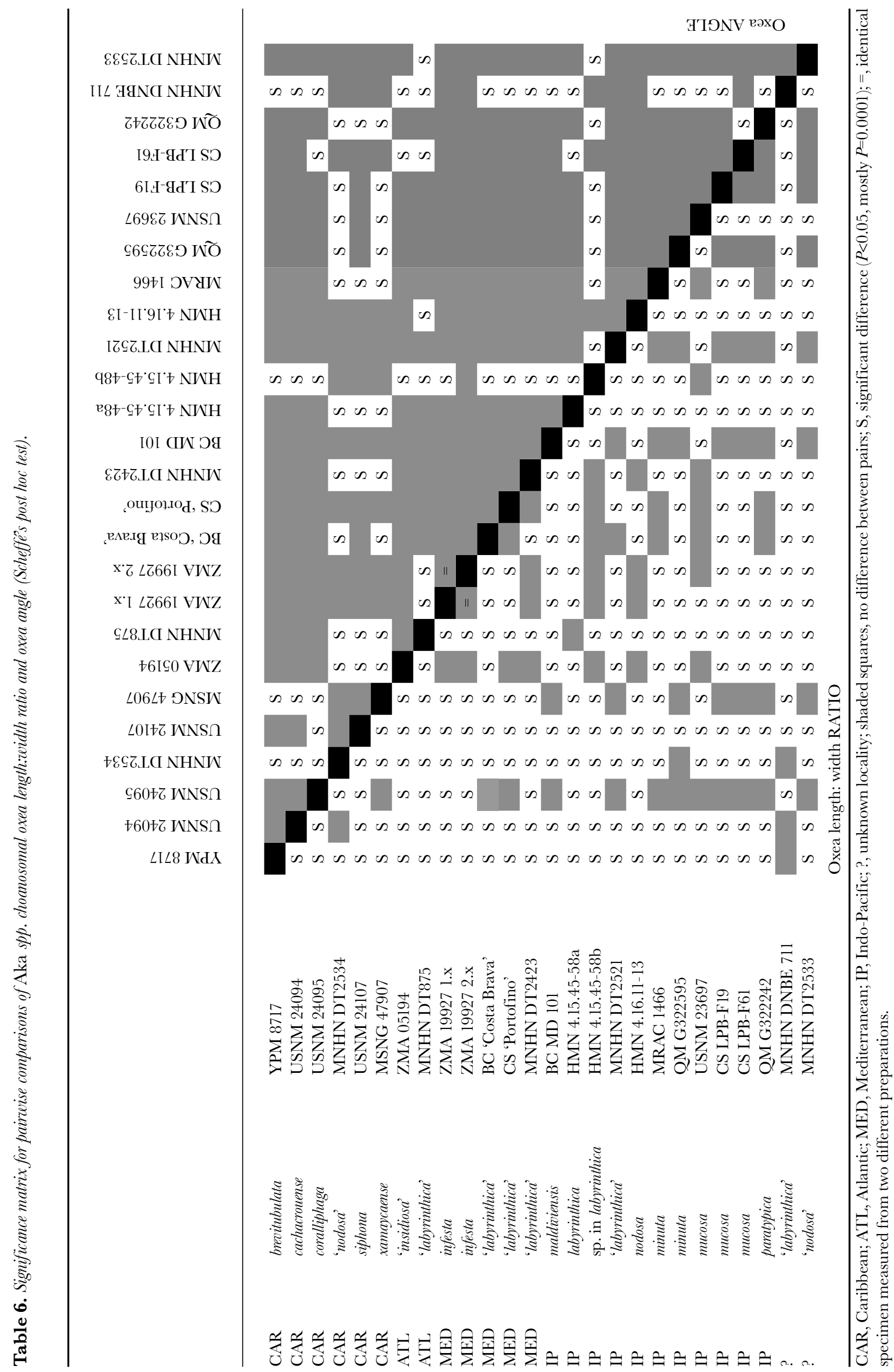



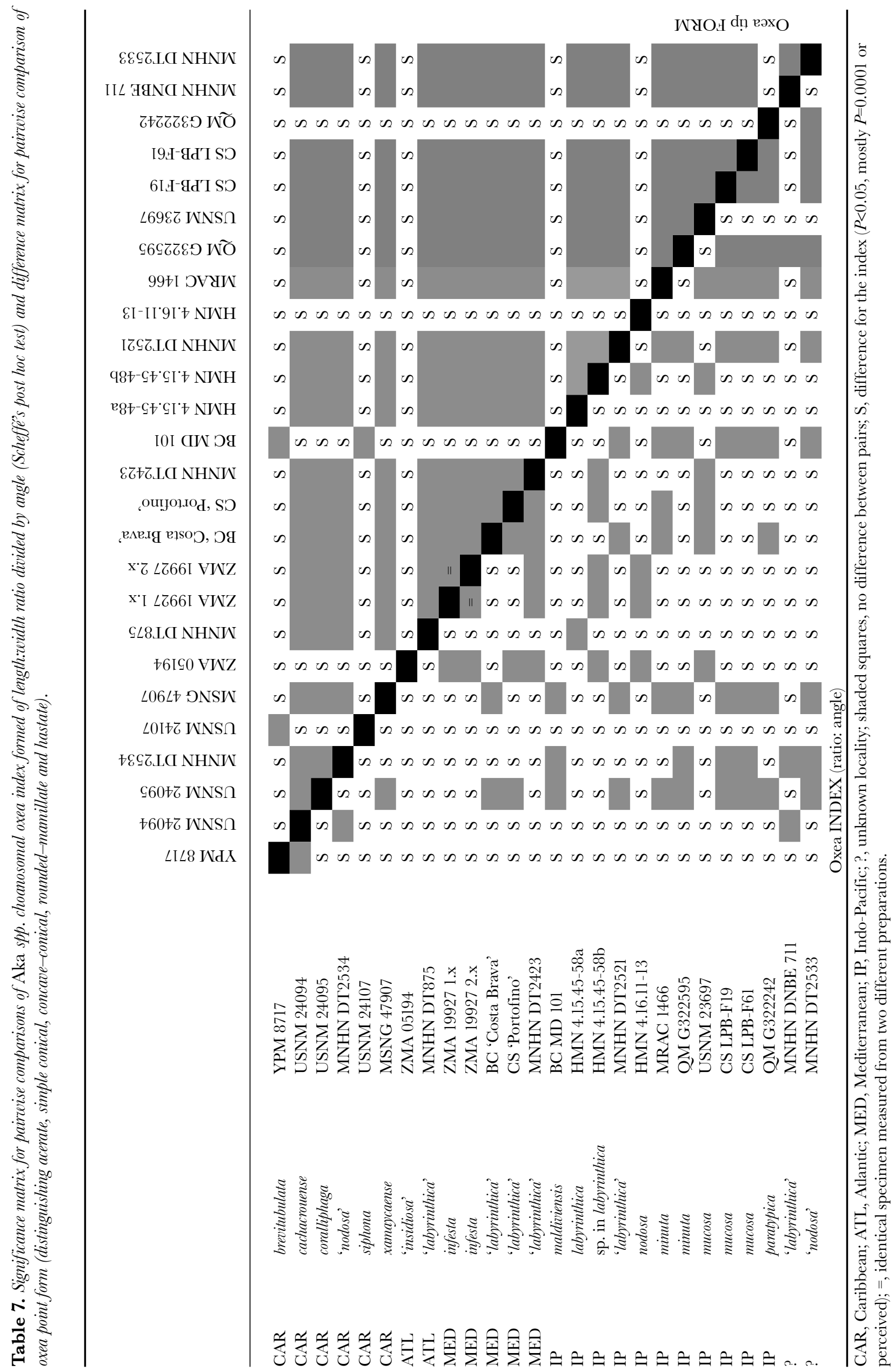

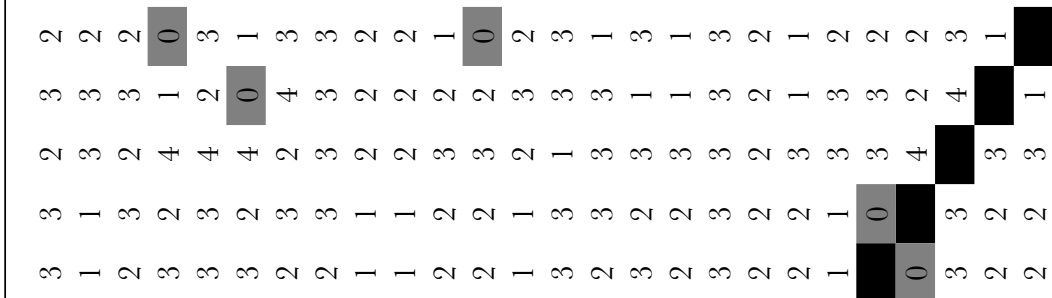

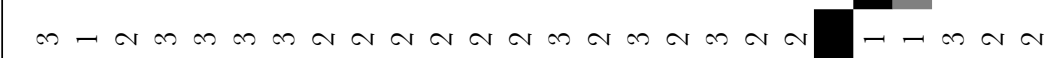

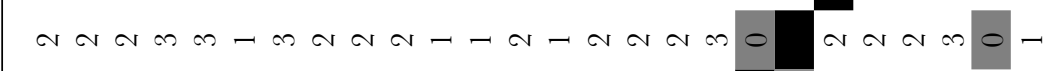

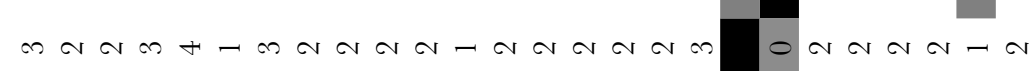

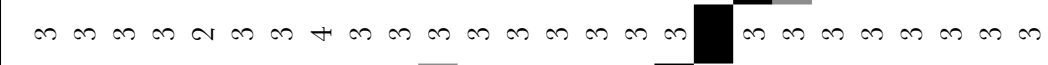

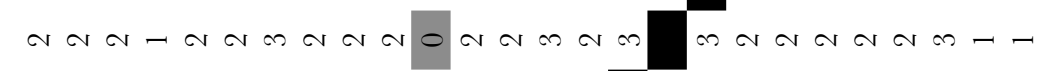
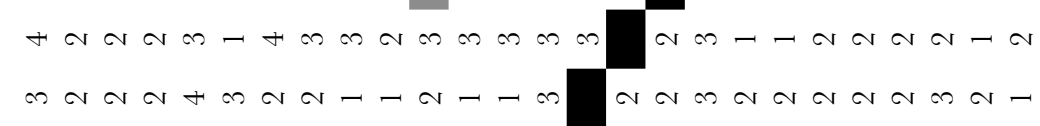

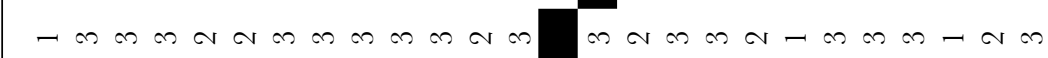
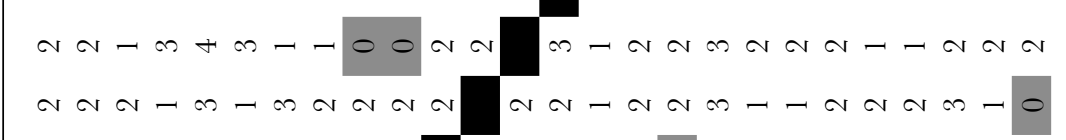

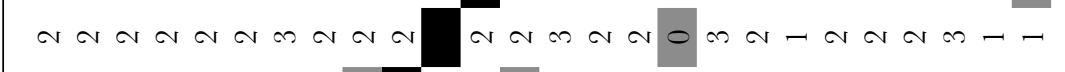

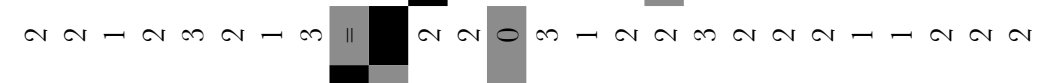

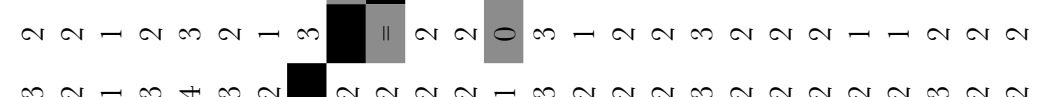

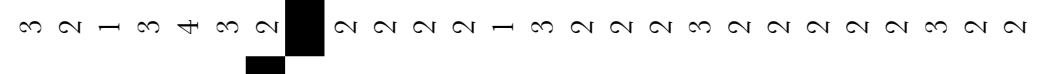

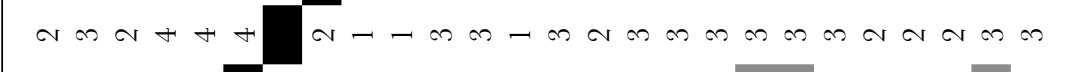

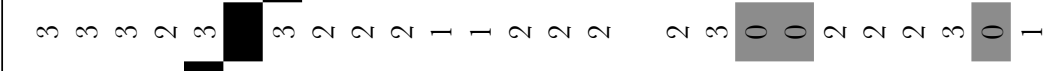

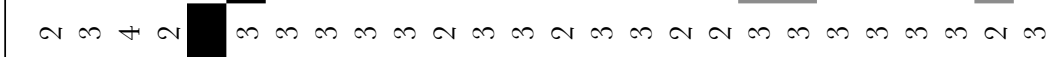

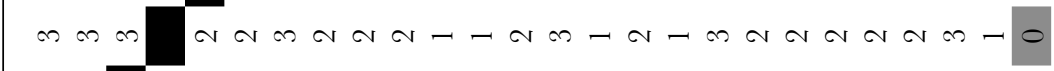

(n)

m

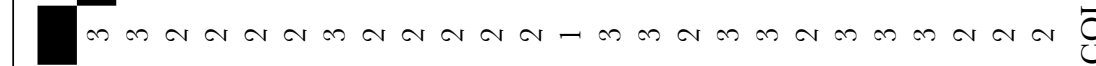

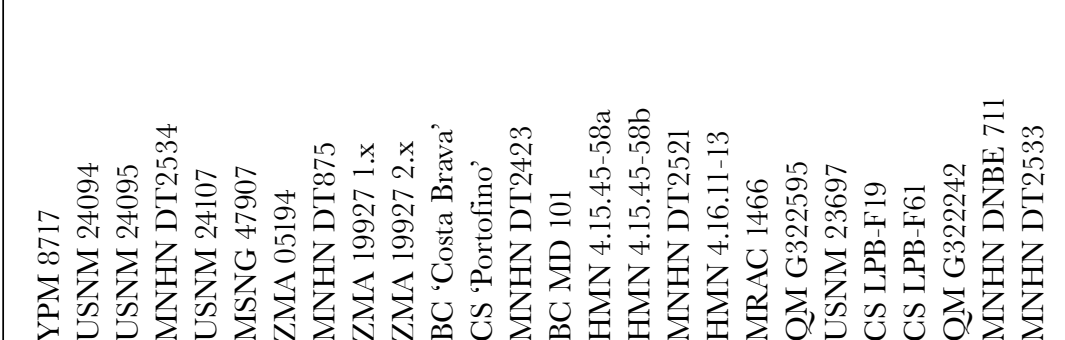

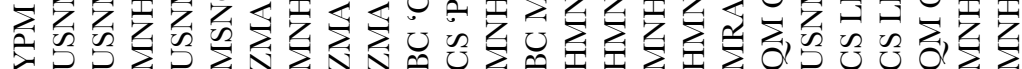

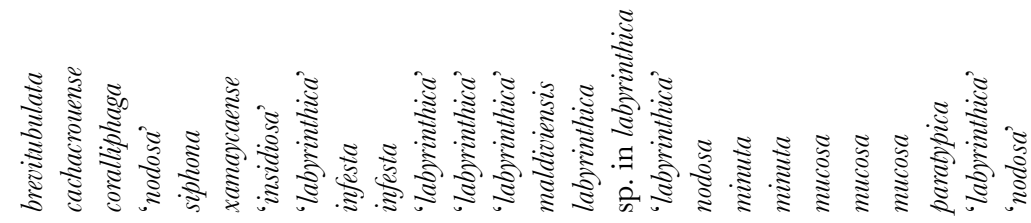

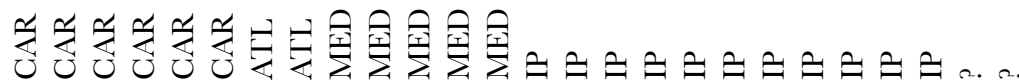


the slimmer oxeas were longer on average and had a less well-pronounced angle than those regarded as typical for $A$. labyrinthica, we discounted the possibility of two size-classes and assumed that the sample was not monospecific. A third kind of oxeas in the A. labyrinthica type series was unlikely to belong to yet another species of $A k a$, because the actines tapered uncharacteristically along the entire length of the shafts, and their mean length surpassed presently known values in other $A k a$ spp. (a mean of $245 \mu \mathrm{m}, \mathrm{N}=11$; Figure $5 \mathrm{C})$.

Of the two $A k a$-like oxea types in Hancock's material for A. labyrinthica, the first kind with well-formed bends matches Hancock's (1849) description better than the second and is presently regarded as the source material of the holotype (see Table 1). This material visually and statistically differed from those of all other specimens in the present study, including all Mediterranean samples (Table 8). Four samples differed with only one spicule character, but are here regarded as not conspecific with $A$. labyrinthica: samples $A$. infesta ZMA POR 19927 and 'A. labyrinthica' MNHN DT2423 had too long oxeas, and 'A. nodosa' MNHN DT2533 and 'Portofino' had simultaneously markedly slimmer oxeas with weaker bends. To our present knowledge, A. labyrinthica has not been sampled since its original description from the Indo-Pacific and has no confirmed record from the Mediterranean. The Mediterranean samples listed here differ from A. labyrinthica. Presently we can distinguish three or four Mediterranean species of $A k a$ : the Ionian Sea sample ZMA POR 19927 of $A$. infesta, which may or may not be conspecific with MNHN DT2423 from the Gulf of Lion, and the samples 'Costa Brava' and 'Portofino' that differ from the above samples and from each other.

Despite obvious differences between known samples, $A k a$ spp. from the Mediterranean have traditionally been called 'A. labyrinthica'. Not having access to Hancock's and Johnson's type specimens, a number of authors apparently relied on previous decisions. The first person to err was Topsent (1900, 1904), who wrongly identified material from the Indo-Pacific, the French Mediterranean and on the Azores as 'A. labyrinthica' (Table 1). Topsent lived at a time when decisions were mainly made by referring to the available literature, and sample exchange may have been a rare occasion. He did not have much choice between known species, as only five had been described by 1900Hancock's and Johnson's - and in the beginning Topsent was not even yet aware of the Johnson species. Therefore, in Topsent's experience, his specimens were to be either A. labyrinthica, A. nodosa or a new species, and he chose to conform to the known species. He was a very thorough sponge taxonomist far above the average for his period. It is thus understandable that authors listed in Table 1 did not question his decisions and relied on the previous reports of 'A. labyrinthica' from the Mediterranean and Atlantic, especially as it was an easy slip to assume that Hancock's (1849) samples were mostly from Great Britain (e.g. Desqueyroux-Faundez \& Valentine, 2002). However, we now know that Topsent's conclusions were wrong and that his samples contained different, in part undescribed species. We therefore suggest that re-evaluation of all samples from the Mediterranean will be essential.
Our study revealed that there is more diversity in the genus $A k a$ than previously thought and that a comparatively 'nondescript' spicule such as the oxea can impart a number of very useful characters. A combination of as few as four characters (spicule length, width, tip form and angle) can generate enough information to distinguish species at a high level of accuracy. The standardized procedure used here may be helpful in other genera with little spicular diversity as well, as long as one keeps in mind that data need to meet requirements for statistical evaluation and that environmental variation may occasionally influence them (e.g. Uriz et al., 2003).

We sincerely thank the Captain, crew and colleagues of the RV 'Urania', and especially A. Vertino (Bologna), for their skilful support, and M. Taviani (Bologna) for giving us the sample. L.B. is supported by the HERMES project, EG contract no. GOCE-CT-2005-511234, funded by the European Commission's Sixth Framework Programme under the priority 'Sustainable Development, Global Change and Ecosystems'. The following colleagues greatly assisted us by checking their museum collections, if in vain: A. Cartaxana and J. Prudencio (Lisbon), R.M. George (Cochin), D. Gordon (Newcastle upon Tyne), H. Szmutka (Frankfurt) and M.-D. Wandhammer (Strasbourg), or by sending us specimen material for biometric studies of spicules: E. Beglinger (Amsterdam), B. Calcinai (Ancona), I. Domart-Coulon (Paris), E. Lazo-Wasem (New Haven), K. Rützler (Washington; also a big thanks for the colour chart from the Royal Horticultural Society and the photographs of the Hancock material!), and D. van den Spiegel (Tervuren). S. Martyna helped at the SEM unit at the Oldenburg University. R. Sieger input the data at PANGAEA ${ }^{\circledR}$. The present paper is a result of discussions during the 5th International Bioerosion Workshop in Erlangen, Germany and would not otherwise have been written. W. Ahlrichs generously allowed C.S. to use microscopic and photographic equipment for lengthy sessions of spicule measurements. C.S. is grateful for various ways the organizers supported her participation.

\section{REFERENCES}

Alander, H., 1942. Sponges from the Swedish west-coast and adjacent waters. PhD thesis, University Göteborg, Sweden, 95 pp, 16 pls.

ARKive. Images of life on earth. Giant clam (Tridacna gigas). Available at: http://www.arkive.org/species/GES/invertebrates_ marine/Tridacna_gigas/more_info.html [accessed 22-06-2006.]

Barletta, G. \& Vighi, M., 1968. Ricerche sul corallo rosso: 5poriferi perforanti. Rendiconti Istituto Lombardo Accademia die Scienze e Lettre, Milano. B Scienze Biologiche e Mediche, 102, 145-159.

Beuck, L. \& Freiwald, A., 2005. Bioerosion patterns in a deepwater Lophelia pertusa (Scleractinia) thicket (Propeller Mound, northern Porcupine Seabight). In Cold-water corals and ecosystems (ed. A. Freiwald and J.M. Roberts), pp. 915-936. Erlangen Earth Conference Series. Berlin: Springer.

Boury-Esnault, N. \& Van Beveren, M., 1982. Les Démosponges du plateau continental de Kerguelen-Heard. Comité National Français des Recherches Antarctiques, 52, 1-175.

Calcinai, B., Arillo, A., Cerrano, C. \& Bavestrello, G., 2003, Taxonomy-related differences in the excavating micro-patterns of boring sponges. Fournal of the Marine Biological Association of the United Kingdom, 83, 37-39.

Calcinai, B., Cerrano, G., Bavestrello, G., Milanese, M. \& Sarà, M., 2000a. Il popolamento di spugne perforatrici di Corallium rubrum e di alcuni madreporari del Promontorio di Portofino. Bolletino dei Musei e degli Istituti Biologici dell'Università di Genova, 64-65, 53-59. 
Calcinai, B., Cerrano, G., Sarà, M. \& Bavestrello, G., $2000 \mathrm{~b}$. Boring sponges (Porifera, Demospongiae) from the Indian Ocean. Italian Fournal of Zoology, 67, 203-219.

Carter, H.J., 1882. New sponges, observations on old ones, and a proposed new group. Annals and the Magazine of Natural History, Series 5, 10, 106-125 and Series 5, 11, 344-369, pls 14-15.

Corriero, G., Abbiati, M. \& Santangelo, G., 1997. Sponges inhabiting a Mediterranean red coral population. Pubblicazioni della Stazione Zoologica di Napoli: Marine Ecology, 18, 147-155.

Cruz, T. \& Bacallado, J.J., 1983. Esponjas perforantes (Porifera, Clionidae) de Tenerife, Islas Canarias. Vierea, 12, 37-48.

Cruz Simó, T., 2002. Esponjas marinas de Canarias. Canary Islands: Banco de Datos de Biodiversidad.

Desqueyroux-Faúndez, R. \& Valentine, G., 2002. Family Phloeodictyidae Carter, 1882. In Systema Porifera: a guide to the classification of sponges, vol. 1 (ed. J.N.A. Hooper and R.W.M. van Soest), pp. 893-905. New York: Kluwer Academic/Plenum Publishers.

Fromont, J., 1993. Descriptions of the Haplosclerida (Porifera: Demospongiae) occurring in tropical waters of the Great Barrier Reef. The Beagle, Records of the Northern Territory Museum of Arts and Science, 10, 7-40.

Hancock, A., 1849. On the excavating powers of certain sponges belonging to the genus Cliona; with descriptions of several new species, and an allied form. Annals and Magazine of Natural History, Series 3, 19, 229-242.

Johnson, J.Y., 1899. Notes on some sponges belonging to the Clionidae obtained at Madeira. Fournal of the Royal Microscopical Society. Transactions of the Society, 9, 461-463.

Laubenfels, M.W. de, 1936. A discussion of the sponge fauna of the Dry Tortugas in particular, and the West Indies in general, with material for a revision of the families and orders of the Porifera. Carnegie Institution of Washington Publications 467, also Papers of the Tortugas Laboratory, 30, 1-225.

Melone, N., 1965. I poriferi associati a Corallium rubrum (L.) della Sardegna. Annali del Museo Civico di Storia Naturale Giacomo Doria, 75, 344-358.

Pang, R.K., 1973. The systematics of some Jamaican excavating sponges (Porifera). Postilla of the Peabody Museum of Yale University, 161, $1-75$.

PANGAEA $^{\circledR}$. Publishing Network for Geoscientific \& Environmental Data. Available at: http://www.pangaea.de/ [accessed 19-09-2007.]

Pulitzer-Finali, G., 1983. A collection of Mediterranean Demospongiae (Porifera) with, in appendix, a list of Demospongiae hitherto recorded from the Mediterranean Sea. Estratto dagli Annali del Museo Civico di Storia Naturale Giacomo Doria di Genova, 84, 445-621.

Pulitzer-Finali, G., 1986. A collection of West Indian Demospongiae (Porifera). In appendix, a list of the Demospongiae hitherto recorded from the West Indies. Estratto dagli Annali del Museo Civico di Storia Naturale Giacomo Doria di Genova, 86, 65-216.
Rosell, D. \& Uriz, M.-J., 2002. Excavating and endolithic sponge species (Porifera) from the Mediterranean: species descriptions and identification key. Organism Diversity and Evolution, 2, 55-86.

Rützler, K., 1971. Bredin-Archbold-Smithsonian Biological Survey of Dominica: burrowing sponges genus Siphonodictyon Bergquist, from the Caribbean. Smithsonian Contributions to Zoology, 77, 1-37.

Rützler, K. \& Stone, S.M., 1986. Discovery and significance of Albany Hancock's microscope preparations of excavating sponges (Porifera: Hadromerida: Clionidae). Proceedings of the Biological Society Washington, 99, 658-675.

Schönberg, C.H.L. \& Barthel, D., 1997. Inorganic skeleton of the demosponge Halichondra panicea. Seasonality in spicule production in the Baltic Sea. Marine Biology, 130, 133-140.

Schönberg, C.H.L. \& Tapanila, L., 2006. The bioeroding sponge Aka paratypica, a modern tracemaking analogue for the Palaeozoic ichnogenus Entobia devonica. Ichnos, 13, 147-157.

Sollas, W.J., 1885. A classification of the sponges. Annals and Magazine of Natural History, Series 5, 16, 395.

Thomas, P.A., 1972. Boring sponges of the reefs of Gulf of Mannar and Palk Bay. In Proceedings of the first Symposium Corals and Coral Reefs at Mandapam Camp, India (ed. C. Mukundan and C.S. Gopindu Pillai). Fournal of the Marine Biological Association of India, 333-362.

Topsent, E., 1888. Contribution à l'étude des Clionides. Archives de Zoologie Expérimentale et Générale, 2, suppl. 1887, 1-165, 7 pls.

Topsent, E., 1900. Étude monographique des spongiaires de France. 3 Monaxonida (Hadromerina). Archives de Zoologie Expérimentale et Générale, 3, 1-331, pls 1-8.

Topsent, E., 1904. Spongiaires des Açores. Résultats des Campagnes Scientifiques du Prince de Monaco, 25, pp. 1-276, 18 pls. Monaco: Imprimerie de Monaco.

Topsent, E., 1928. Spongiaires de l'Atlantique et de la Méditerranée provenant des croisières du Prince Albert ler de Monaco. Résultats des Campagnes Scientifiques accomplies par le Prince Albert I de Monaco, 74, pp. 1-376, pls I-XI. Monaco: Imprimerie de Monaco.

UNEP-WCMC. UNEP-WCMC species database: CITES-listed species. Available at: http://sea.unep-wcmc.org/isdb/CITES/Taxonomy/ tax-species-result.cfm? Genus=Tridacna\&Sp ecies=gigas\&source $=$ animals\&tabname $=$ distribution [accessed 22-06-2006.]

Uriz. M.-J., Turon, X., Becerro, M.A. \& Agell, G., 2003. Siliceous spicules and skeleton frameworks in sponges: origin, diversity, ultrastructural patterns, and biological functions. Microscopy Research and Technique, 62, 279-299.

Wiedenmayer, F., 1977. Shallow-water sponges of the western Bahamas, 287 pp., 43 pls. Basel: Birkhäuser Verlag.

Submitted 30 April 2007. Accepted 26 October 2007. 